\title{
1 Antimony measurements in environmental matrices: Seven considerations
}

2

3 William A. Maher ${ }^{1}$, Frank Krikowa ${ }^{1}$, Simon Foster ${ }^{1}$, Michael J. Ellwood ${ }^{2}$ and William W.

4 Bennett $^{3}$

$5 \quad{ }^{1}$ Ecochemistry Laboratory, Institute for Applied Ecology, University of Canberra, Bruce

6 ACT 2601

$7 \quad{ }^{2}$ Research School of Earth Sciences, Australian National University, Canberra, Australian

8 Capital Territory, Australia

$9 \quad{ }^{3}$ Environmental Futures Research Institute, Griffith School of Environment and Science,

10 Griffith University, Gold Coast, QLD Australia

11

12

13

14 No of pages: 13

$15 \quad$ No of Figures 2

16

17

$18 \quad 26$ May 2018

19 


\section{Abstract}

21 The development of robust methods for determining the concentration and speciation of antimony (Sb) in natural samples is essential to understanding its distribution and cycling in nature. Here we discuss our experiences with a variety of approaches for measuring the content and speciation of Sb in environmental matrices. Total Sb concentration measurements in waters require digestion with $\mathrm{HNO}_{3}-\mathrm{HCl}$ to release $\mathrm{Sb}$ from particulate material and may require a preconcentration step to remove $\mathrm{Sb}$ from saline matrices or to obtain the required sensitivity. Plant analyses require the use of $\mathrm{HNO}_{3}-\mathrm{HBF}_{4}$ or $\mathrm{HNO}_{3}-\mathrm{HF}$ while sediments require the use of $\mathrm{HNO}_{3}-\mathrm{HCl}$ to solubilise $\mathrm{Sb}$ and prevent adsorption to silicates. Methods for Sb speciation should be fit for purpose. Volatile Sb species can be measured successfully using SPME-GCMS, waters via hydride generation-trapping ICPMS and sediment extracts using HPLC-ICPMS. Extraction of Sb from sediments and plants presents a challenge; however, the use of citrate is adequate for extraction of $\mathrm{Sb}$ from sediments predominately containing Sb associated with Fe-Mn oxyhydroxide phases. We have been unable to successfully quantify organic Sb species in plants because of the oxidation of $\mathrm{Sb}$ (III) to $\mathrm{Sb}$ (V) and the degradation and transformation of organic Sb species. The analysis of solid samples using $\mathrm{x}$-ray absorption spectroscopy should be considered as it has been shown to discriminate between $\mathrm{Sb}(\mathrm{III})$ and $\mathrm{Sb}(\mathrm{V})$ as well as $\mathrm{Sb}$ minerals, oxides and adsorbed $\mathrm{Sb}$ species. 
41 Understanding the environmental cycling and toxicology of antimony (Sb) has gained 42 increased attention in recent years. Antimony used to be found mainly in elevated 43 concentrations in soils near mines and systems receiving mine runoff.$^{1-3}$ In addition, Sb is 44 used in flame retardants, brake linings, batteries, PET bottles, pharmaceuticals and paints, 45 which are also potential sources to the environment. ${ }^{4-11}$ Environmental Sb analysis has been 46 extended to roadside dust, atmospheric particles, plants and animals. ${ }^{12-16}$ As well as total Sb 47 concentrations, the speciation of $\mathrm{Sb}$ is required to understand antimony's mobility and 48 toxicology. Antimony is considered to be non-essential for plants and animals ${ }^{4}$ and there is 49 concern about its potential toxicity and other biological effects to plants and animals.

50 Antimony occurs mainly in inorganic forms as $\mathrm{Sb}(\mathrm{III})$ and $\mathrm{Sb}(\mathrm{V}){ }^{17,}, 18$ while methyl Sb 51 species $\left(\mathrm{CH}_{3} \mathrm{SbX},\left(\mathrm{CH}_{3}\right)_{2} \mathrm{SbX},\left(\mathrm{CH}_{3}\right)_{3} \mathrm{Sb}\right)$ have been reported in seawater, ${ }^{19,}{ }^{20}$ freshwater, ${ }^{3}$ 52 geothermal waters, ${ }^{21}$ sediments and sediment pore waters, ${ }^{22}$ bacterial cultures, ${ }^{23,}{ }^{24}$ landfill 53 gases ${ }^{25}$ and plants. ${ }^{3,26,27}$

54 We have been analysing Sb in environmental matrices for over 20 years and in this paper, we 55 discuss our experiences in measuring the content and speciation of $\mathrm{Sb}$ in bacterial cultures, 56 waters, sediments, plants and animal tissues. We have structured the discussion around seven 57 questions that should be considered before undertaking Sb analyses. 


\section{Question 1: Can you measure total Sb concentrations?}

Total Sb concentrations are required to assess the distribution and movement of $\mathrm{Sb}$ in the environment. As well, accurate $\mathrm{Sb}$ analyses are required for speciation purposes to measure mass balances (extraction efficiencies, column recoveries etc.). Different procedures are required for different matrices (Figure 1)

\section{Water}

Analysis of total Sb concentrations in water and waste waters may require a pre-digestion step to release Sb from particulate material. In our laboratory, microwave digestion is used extensively with $\mathrm{HNO}_{3}-\mathrm{HCl}(2 ; 1 \mathrm{v} / \mathrm{v}) ; 1 \mathrm{~mL}$ of acid mixture to $10 \mathrm{~mL}$ of sample at $150{ }^{\circ} \mathrm{C}$ for 30 min with analyses by ETAAS or ICPMS. If pre-concentration or separation from saline matrices is required, we use pre-concentration by co-precipitation, chelation-solid phase extraction and/or hydride generation. ${ }^{12,20,28}$ Digestion, however, is not always necessary or desired; for example, the measurement of Sb in bottled water ${ }^{29}$. As well, in toxicity studies, the aim may be to distinguish between particulate and dissolved Sb thus filtration not digestion is required.

\section{$\underline{\text { Biota }}$}

For the analysis of animal tissues, most digestion procedures employ $\mathrm{HNO}_{3}$ or $\mathrm{HNO}_{3} / \mathrm{H}_{2} \mathrm{O}_{2}$ and microwave heating to quantitatively recover $\mathrm{Sb}^{30}$ Plants, however, require a different digestion procedure if samples contain significant amounts of silica. In 2002, ${ }^{30}$ we digested all the available certified reference materials) and found a bias of $\sim 25 \%$ resulting in lower measured Sb concentrations $\left(y=0.745 x+0.0163, r^{2}=0.900, n=90\right)$. At that time, only a few certified reference materials were available and hence our confidence in the Sb values reported in the literature was low. Subsequently we made a comparison of the efficiency of digesting samples using $\mathrm{HNO}_{3}$ and $\mathrm{HNO}_{3}-\mathrm{HBF}_{4}$ (with the results indicating that underestimation of Sb concentrations occurs in some plant samples containing silica). ${ }^{13}$ This has also been reported by several other studies. ${ }^{31,32}$ Reanalysis of available certified reference materials including more recently produced ones has shown the use of $\mathrm{HNO}_{3}-\mathrm{HBF}_{4}$ for digestion removes this bias $\left(y=1.009 x+0.0002, r^{2}=0.940, n=80\right)$. The use of $\mathrm{HBF}_{4}$, however, may cause minor problems during ICPMS analysis; these problems include the etching of glass nebulisers and alumina injectors. Traditionally, excess HF is complexed using $\mathrm{H}_{3} \mathrm{BO}_{3}{ }^{33}$. We prefer not to use boric acid as it can cause nebulisation and plasma effects during ICPMS analyses. In practice, the small bias may not be an issue but needs to be considered before choosing the appropriate digestion acids. We have investigated the Sb species in digests and found in all cases that $\mathrm{Sb}$ was present as $\mathrm{Sb}(\mathrm{V}) .{ }^{13}$ This was expected as $\mathrm{HNO}_{3}$ would convert inorganic $\mathrm{Sb}$ to $\mathrm{Sb}(\mathrm{V})$. Hydride generation can be used for total $\mathrm{Sb}$ measurements as all Sb species have been found to degrade to inorganic Sb. More recently, we have evaluated the use of $\mathrm{HNO}_{3}-\mathrm{H}_{2} \mathrm{O}_{2}-\mathrm{HCl}$ and closed vessel microwave digestion at 180 ${ }^{\circ} \mathrm{C}$ for 15 min for digestion of plant samples and obtained 102-119\% recovery of Sb from 
NIST citrus leaves. ${ }^{34}$ Thus, Sb is not adsorbing to silicates and provides a suitable alternative to the use of $\mathrm{HBF}_{4}$

\section{$\underline{\text { Sediments and soils }}$}

Evaluation of sediment extraction methods have clearly shown that using $\mathrm{HNO}_{3}$ or $\mathrm{HNO}_{3} / \mathrm{HClO}_{4}$ results in incomplete recoveries of Sb; probably due to the formation of insoluble oxides such $\mathrm{Sb}_{2} \mathrm{O}_{5}, \mathrm{SbO}_{4}(\mathrm{OH})_{2}\left(\mathrm{NO}_{3}\right)$ etc. and/or the adsorption of Sb-oxyhydroxy compounds onto silicate minerals. ${ }^{35}$ The use of $\mathrm{HCl}$ as part of the digestion mixture is mandatory to solubilise $\mathrm{Sb}(\mathrm{V})$ as $\mathrm{SbCl}_{6}{ }^{-}$and prevent $\mathrm{Sb}$ adsorption to silica material. ${ }^{36}$ The use of $\mathrm{HCl}$ has the added advantage of dissolving common iron and silica minerals and apatite. ${ }^{37}$ We have evaluated the use of $\mathrm{HNO}_{3}-\mathrm{HCl}$ mixtures for releasing $\mathrm{Sb}$ from mine contaminated sediments ${ }^{38}$ and found Sb is nearly quantitatively extracted (using a 2:1 v/v $\mathrm{HNO}_{3}-\mathrm{HCl}$ mixture $(92-97 \% ; 95 \pm 2 \%, \mathrm{n}=6)$. The use of elevated temperature $\left(150{ }^{\circ} \mathrm{C}\right)$ enhances the dissolution of Sb containing phases. ${ }^{37}$ In these sediments, Sb is adsorbed to Fe/Mn oxyhydroxides or silicates. ${ }^{38-40}$ More recently, the use of a using a 3:1 v/v $\mathrm{HNO}_{3}-\mathrm{HCl}$ mixture has given good recoveries (>93\%) from a certified stream sediment. ${ }^{34}$ In soils, not from shooting ranges where Sb id likely to be in spent bullets, Sb is also likely to be substantially adsorbed to Fe/Mn oxyhydroxides. At shooting ranges $\mathrm{Sb}$ is likely to be a bronze alloy. Mine mineral associated Sb will be mainly Sb sulphides ${ }^{41-43}$ and conventional aqua regia (3:1 v/v $\left.\mathrm{HNO}_{3}-\mathrm{HCl}\right)$ probably will be required to release and retain Sb into solution. ${ }^{44-47}$ Other soils and sediments may require the use of HF for the complete recovery of $\mathrm{Sb}^{48}$

\section{Antimony speciation measurements}

\section{Question 2: Have you chosen the most appropriate speciation method?}

The aim of speciation procedures is to maintain the integrity of Sb species and minimise sample preparation procedures that may alter Sb speciaton. There is a tendency for laboratories to choose methods they are familiar with rather than the most appropriate procedures likely to obtain accurate and unambiguous speciation data. Similar to total Sb concentration measurements, appropriate procedures need to be used to undertake Sb speciation measurements (Figure 2). Speciation results are dependent on the separation mechanisms selected i.e. size exclusion, ion exchange, reverse phase etc. For example, ion exchange is typically used to measure $\mathrm{Sb}(\mathrm{III})$ and $\mathrm{Sb}(\mathrm{V})$ redox states rather than single $\mathrm{Sb}$ entities.

\section{$\underline{\text { Volatile Sb species }}$}

There have been numerous studies investigating volatile methylated Sb species produced by bacterial cultures and landfills. ${ }^{23-25}$ The most appropriate procedures are those that trap Sb species and undertake measurements without derivatisation. Most published procedures cryogenically trap Sb species and analyse individual Sb species by ICPMS or other spectroscopic methods. ${ }^{3,21,49}$ The boiling points of volatile species are $\mathrm{SbH}_{3}\left(-17^{\circ} \mathrm{C}\right)$, $\mathrm{CH}_{3} \mathrm{SbH}_{2}\left(41^{\circ} \mathrm{C}\right),\left(\mathrm{CH}_{3}\right)_{2} \mathrm{SbH}\left(61^{\circ} \mathrm{C}\right)$ and $\left(\mathrm{CH}_{3}\right)_{3} \mathrm{Sb}\left(81^{\circ} \mathrm{C}\right)$, respectively, and can be 
immobilised in a liquid $\mathrm{N}_{2}$ trap packed with a GC chromatographic phase. ${ }^{20}$ Programmed heating is used to release individual Sb species for analysis. Alternatively, solid-phase micro extraction (SPME) procedures utilising polydimethylsiloxane phases can be used to trap head space gases. We have used SPME to trap volatile Sb species in the head space of bacterial cultures and used GC-MS to analyse Sb species. ${ }^{49}$ A cryogenic $\left(\mathrm{CO}_{2}\right.$ cooled) injection port is required and again programmed heating is used to separate and measure Sb species. The advantages of these procedures are that no derivatisation is required prior to sample analysis. The use of mass spectrometry has the added advantage of unequivocal identification of Sb species.

\section{$\underline{\text { Waters }}$}

Normally river and seawaters not receiving mine wastes have low Sb concentrations and require preconcentration of Sb species before analysis. The formation of volatile Sb species $\left(\mathrm{SbH}_{3}, \mathrm{CH}_{3} \mathrm{SbH}_{2},\left(\mathrm{CH}_{3}\right)_{2} \mathrm{SbH}\right.$ and $\left.\left(\mathrm{CH}_{3}\right)_{3} \mathrm{Sb}\right)$ via the use of sodium tetrahydroborate (III) has been used successfully for open ocean seawater samples. ${ }^{20}$ Similar to that described for volatile Sb species, a cryogenic trapping system is used prior to measurement by ICPMS or other spectrometric methods. ${ }^{20,26,27,50-52}$ The efficiency of hydride generation is critically dependent on sample $\mathrm{pH}$. The formation of $\mathrm{SbH}_{3}$ from $\mathrm{Sb}(\mathrm{III})$ occurs over a wide $\mathrm{pH}$ range (1-7) but $\mathrm{Sb}(\mathrm{V})$ reduction markedly decreases as $\mathrm{pH}$ increases. ${ }^{19,20}$ The use of a reducing agent such as cysteine or potassium iodide allows quantitative reduction of $\mathrm{Sb}(\mathrm{V})$ to $\mathrm{Sb}(\mathrm{III})$ at higher $\mathrm{pH} .{ }^{12,20}$ The problem with these procedures is minimising the disproportionation of $\left(\mathrm{CH}_{3}\right)_{3} \mathrm{Sb}$ into other Sb species. ${ }^{26,50,53}$ The use of surface passivation, low acid strength (pH $>1$ ), exclusion of oxygen and the use of a chelating agent such as cysteine to promote the reduction of $\mathrm{Sb}(\mathrm{V})$ to $\mathrm{Sb}(\mathrm{III})$ for hydride generation, along with the suppression of interferences from Fe, Ni, Co, Cu etc. are all required. ${ }^{20,26,27,54}$ We have described a fully automated hydride generation-trapping ICPMS system that satisfies these conditions. ${ }^{20}$ Published data using batch hydride generation systems indicates that they suffer from disproportionation problems. ${ }^{26,27}$ We have found that the fully automated system, that has no glass components, also reduces contamination, i.e. lower blanks, and has much better reproducibility compared to batch systems. The trapping of Sb species critically depends on the chromatographic packing used in the trapping system so particular attention should be given to this aspect of the system.

\section{$\underline{\text { Sediments and plants }}$}

HPLC-ICPMS has been used extensively to analyse sediment and plant extracts. ${ }^{38,55,56}$ The use of a PRP-X100 column with an EDTA-phthalate buffer is commonly used. ${ }^{50,57}$ We have found these approaches to be suitable for the analysis of citrate extracts of river sediments and soils where Sb has been mobilised from a gold-antimony mine. ${ }^{38}$ Extracts predominately contain $\mathrm{Sb}(\mathrm{V})$ that has been released by the oxidative or reductive dissolution of Sb minerals and readsorbed by Fe/Mn oxyhydroxides and $\mathrm{Al}$ minerals. ${ }^{2,39,40,58,59}$ Citrate is commonly used in sequential extraction schemes to extract Fe and $\mathrm{Mn}$ and associated metals. ${ }^{60}$ Extracts generally have low organic carbon content and thus artefacts are not typically formed. We have not confidently used HPLC-ICPMS to analyse Sb species in plant extracts containing 
appreciable quantities of carbon because of artefact formation (see Question 6). Others have reported similar difficulties in analysing organic rich extracts such as orange juice and yoghurt. $^{29,61}$

\section{Question 3: Do you have confidence in Sb speciation standards?}

There are various ways of preparing inorganic $\mathrm{Sb}(\mathrm{III})$ and $\mathrm{Sb}(\mathrm{V})$ standards. We prefer to use $\mathrm{KSb}(\mathrm{III})$ tartrate $\left(\mathrm{KSb}_{2}\left(\mathrm{C}_{4} \mathrm{O}_{6} \mathrm{H}_{2}\right)_{2}{ }^{2-}\right)$ and $\mathrm{KSb}(\mathrm{V})(\mathrm{OH})_{6}$ as forms of $\mathrm{Sb}(\mathrm{OH})_{3}$ and $\mathrm{Sb}(\mathrm{OH})_{6}{ }^{-}$, respectively, as these are readily soluble in water to at least $1 \mathrm{mg} \mathrm{Sb} \mathrm{L^{-1 }} .^{62}$ Other available compounds such as $\mathrm{SbCl}_{3}$ and $\mathrm{Sb}_{2} \mathrm{O}_{5}$ are not sufficiently soluble. Antimony (V) standards are stable for long periods, however, $\mathrm{Sb}(\mathrm{III})$ standards oxidise over short periods i.e. days. Antimony (III) standards can be stabilised by adding citrate to form stable Sb(III)-citrate complexes. ${ }^{63}$ However, it should be noted that the ICPMS signals of Sb complexed with EDTA, tartrate or citrate may give different responses to aqueous standards, ${ }^{28}$ so care must be taken to match the Sb species used for calibration curves.

Trimethyl Sb halides ( $\mathrm{X}=$ chloride or bromide) are readily synthesised but $\mathrm{CH}_{3} \mathrm{SbX}$, $\left(\mathrm{CH}_{3}\right)_{2} \mathrm{SbX}$ have not been synthesised in sufficient purity to be used as standards. ${ }^{27} \mathrm{We}$ prepare methylated $\mathrm{Sb}$ hydride standards as a mixture by disproportionation of $\left(\mathrm{CH}_{3}\right)_{3} \mathrm{SbCl}$ in glacial acetic acid or by heating under less acidic solutions $(\mathrm{pH}<1)$ with sodium tetrahydroborate (III). $\left(\mathrm{CH}_{3}\right)_{3} \mathrm{SbX}$ readily oxidises to $\left(\left(\mathrm{CH}_{3}\right)_{3} \mathrm{Sb}\right)_{2} \mathrm{O}_{2}$ and $\left(\mathrm{CH}_{3}\right)_{3} \mathrm{SbX}\left(\mathrm{O}_{2} \mathrm{H}\right)_{2}{ }^{64}$ that are not likely to be soluble in water, although it has been suggested it can occur in solution as $\left(\left(\mathrm{CH}_{3}\right)_{3} \mathrm{Sb}(\mathrm{OH})\right)^{+}$and $\left(\left(\mathrm{CH}_{3}\right)_{3} \mathrm{SbOH}_{\mathrm{x}}\left(\mathrm{H}_{2} \mathrm{O}\right)\right)^{+} .{ }^{50}$

\section{Question 4: Can you extract Sb species of interest?}

Any speciation technique that relies on extracting Sb species requires knowledge of extraction efficiencies and species integrity. Hence, trapping of volatile Sb species and water analyses by formation of Sb hydrides is normally preferred because individual species are preserved. We have successfully used microwave extraction with 25-50 mM citric acid to extract large quantities of Sb (50-80\%) from sediments containing Sb mobilised from mining operations, which are associated with Fe-Mn oxyhydroxides and humic acids. ${ }^{2}$, 39,40 Recovery spikes of $\mathrm{Sb}(\mathrm{III})$ and $\mathrm{Sb}(\mathrm{V})$ indicate that $\mathrm{Sb}$ species are stable. This was expected as $\mathrm{Sb}$ species are complexed with citric acid as they are released. We have had less success in extracting Sb from other terrestrial sediments $(<10 \%)$ and air particulates $(<30 \%)$ as, unlike the mine derived sediments, the Sb in these matrices are probably not associated with $\mathrm{Fe} / \mathrm{Mn}$ oxohydroxides. ${ }^{13}$ Others have also reported the low extraction of Sb from soils using citrate extraction ${ }^{65}$ and other extractants. ${ }^{60}$

We have had little success with extracting Sb species from plant tissues using a variety of extractants (e.g. 11\% and 29\% extraction efficiency, respectively, for ferns and algae). ${ }^{13}$ The trend is for lower extraction efficiencies as the total Sb concentration increases. A sequential extraction scheme was designed to remove $\mathrm{Sb}$ associated with lipids $\left(\mathrm{CHCl}_{3}-\mathrm{CH}_{3} \mathrm{OH}\right)$, cytosol $\left(\mathrm{CH}_{3} \mathrm{OH}-\mathrm{H}_{2} \mathrm{O}\right)$ and proteins $\left(\mathrm{HNO}_{3}\right)$ but only 1-6 \% of Sb was extracted, suggesting that $\mathrm{Sb}$ must be associated with other plant constituents. Wang et al ${ }^{66}$ investigated the subcellular distribution of Sb in Fucis tikova and found that 73-88\% Sb was associated with 
cell walls, with only 8-19\% extracted in the cytoplasm. Feng et al ${ }^{67}$ found that $43-89 \%$ of Sb in four ferns was associated cell walls. Thus, these low Sb recoveries are probably a general phenomenon in plants with high Sb concentrations. Wang et al ${ }^{66}$ postulated that the cell wall has many functional groups that can bind with $\mathrm{Sb}$ and restricts its transport into cells protecting the protoplasm from Sb toxicity. The use of enzymes that destroy cell walls may prove successful in releasing Sb from plant material. It is also possible, however, that $\mathrm{Sb}$ is present as nano-particles as reported for other plants that accumulate metals and metalloids. ${ }^{68-}$ ${ }^{70}$ If so, the use of enzymatic hydrolysis coupled with single particle analysis by ICPMS or scanning electron microscopy is required to gain a greater understanding of the nature of $\mathrm{Sb}$ inclusions or particles. We have had some success in extracting Sb from animal tissues. For example, $52 \%$ of Sb could be extracted from DOLT-1 Dogfish tissue using $\mathrm{CHCl}_{3}-\mathrm{CH}_{3} \mathrm{OH}$ (<0.5\%), $\mathrm{CH}_{3} \mathrm{OH}-\mathrm{H}_{2} \mathrm{O}(42 \%)$ and $\mathrm{HNO}_{3}(10 \%)$. We, however, have not information on the stability of Sb species extracted.

\section{Question 5: Do you understand the HPLC chromatography for separating Sb species}

As indicated previously, the most common HPLC technique used to separate Sb species is based on the use of a PRP-X100 anion exchange column with an EDTA-phthalate mobile phase buffer in the $\mathrm{pH}$ 4.5-5 range. Only $\mathrm{Sb}(\mathrm{III})$ forms an EDTA complex and $\mathrm{Sb}(\mathrm{V})$ is chromatographed as $\mathrm{Sb}(\mathrm{OH})_{6}{ }^{-}$and appears near the void volume. As the log $\mathrm{K}$ of the EDTASb complex is much greater that the log K of the tartrate-Sb complex (24.8 compared to 9.4), ${ }^{71}$ EDTA also substitutes for $\mathrm{Sb}(\mathrm{III})$ standards prepared as the tartrate complex. Optimising buffer strength, $\mathrm{pH}$ and temperature only improves the chromatography of the $\mathrm{Sb}$ (III) EDTA complex. If citrate is added to standards before chromatography is undertaken, the $\mathrm{Sb}(\mathrm{III})$ EDTA complex is still formed as $\mathrm{Sb}(\mathrm{III})$-citrate $\log \mathrm{K}$ is lower than the Sb(III)-EDTA $\log \mathrm{K}$ (1.8 and 24.8 respectively at $\mathrm{pH} 6$ ) and the retention time is similar to using EDTA alone (Fig 10). $\mathrm{Sb}(\mathrm{OH})_{6}{ }^{-}$forms a citrate complex and is retained longer on the column. Sufficient citric acid needs to be added to fully complex $\mathrm{Sb}(\mathrm{V})$. In the literature, it has been reported that two Sb $(\mathrm{V})$ citrate complexes (1:1 and 1:2) can be formed. ${ }^{63}$, 72 We have used 25 $\mathrm{mM}$ citric acid for extraction purposes and only found one peak.

\section{Question 6: Are you forming speciation artefacts}

As previously mentioned, we have not had success in determining the Sb species in plant tissue extracts. We conducted a series of experiments in which $\mathrm{Sb}$ (III) and $\mathrm{Sb}(\mathrm{V})$ were added to NIST CRM 1572 citrus leaves pre- and post-extraction. The results revealed considerable change in the oxidation state of $\mathrm{Sb}$ and the creation of chromatographic artefacts. ${ }^{13} \mathrm{Sb}(\mathrm{V})$ complexed with organic matter in extracts producing a number of Sb peaks in addition to the inorganic $\mathrm{Sb}(\mathrm{V})$ peak. Addition of Sb(III) pre-extraction revealed considerable oxidation of $\mathrm{Sb}(\mathrm{III})$ to $\mathrm{Sb}(\mathrm{V})$ while the addition of $\mathrm{Sb}(\mathrm{V})$ pre-extraction resulted in chromatographic artefact formation. The addition of Sb(III) post-extraction resulted in little oxidation of $\mathrm{Sb}(\mathrm{III})$ but addition of $\mathrm{Sb}(\mathrm{V})$ again resulted in artefact formation. Formation of artefacts by $\mathrm{Sb}(\mathrm{V})$ was not surprising as $\mathrm{Sb}(\mathrm{V})$ co-elutes with organic material. ${ }^{13}$ Antimony(V) is known 
to readily complex with organic material in solution. ${ }^{73,74}$ It may be possible to prevent the oxidation of $\mathrm{Sb}(\mathrm{III})$ during extraction by the incorporation of citric acid in the extraction mixture. Amereih et al $^{72}$ examined the effect of temperature on conversion of Sb (III) to $\mathrm{Sb}(\mathrm{V})$ when citrate was used to extract $\mathrm{Sb}$ from soil. As the temperature was raised from 30 to $60{ }^{\circ} \mathrm{C}$, a fraction of the Sb-citrate complex was converted to $\mathrm{Sb}(\mathrm{OH})_{6}{ }^{+}$indicating that although raising the temperature increased extraction efficiencies, Sb oxidation and degradation of Sb-citrate complexes occurred. Gregori et al ${ }^{54}$ also reported the complete oxidation of $\mathrm{Sb}(\mathrm{III})$ to $\mathrm{Sb}(\mathrm{V})$ at $90{ }^{\circ} \mathrm{C}$. As well, many publications have reported poor chromatographic recoveries when analyses are undertaken of Sb species in juices (30\%), ${ }^{61,63}$ urine (51-57\%, K and E), yoghurt (73\%) ${ }^{75}$ and algal extracts $(60 \%) .{ }^{54} \mathrm{As} \mathrm{Sb}(\mathrm{V})$ can be chelated to $\alpha$-hydroxy carboxylic acids ${ }^{76,77}$ and to vincinal hydroxyl groups, ${ }^{73,75}$ low chromatographic recoveries are attributed to incorporation of Sb into polymers. ${ }^{73}$ The prevention of $\mathrm{Sb}(\mathrm{V})$ artefact formation may not be possible.

For animal tissues, the stability of spiked extracts of DORM-2 during, before and after extraction have been investigated. ${ }^{78}$ After 3 days, there was a significant loss of $\mathrm{Sb}(\mathrm{III})(40 \%)$ and $\mathrm{Sb}(\mathrm{V})(40-70 \%)$ and several new Sb species appeared. The new species formed did not account for the loss of inorganic Sb. Again, artefacts are probably formed with organic constituents in extracts.

\section{Question 7: Have you considered the use of X-ray absorption spectroscopy?}

The analysis of solid samples by synchrotron radiation X-ray absorption near edge structure (XANES) spectroscopy has been shown to be capable of discriminating $\mathrm{Sb}(\mathrm{III})$ and $\mathrm{Sb}(\mathrm{V})$ oxidation states ${ }^{8,42,79}$ and has been used to characterise Sb incorporated into and adsorbed onto various minerals. ${ }^{79}$ Antimony speciation in plants exposed to $\mathrm{Sb}(\mathrm{III})$ and $\mathrm{Sb}(\mathrm{V})$ has also been reported. ${ }^{80}$ Sample analysis is performed on cryofixed samples at low temperatures, which is claimed to maintain sample integrity. ${ }^{81}$ Unfortunately, Sb K-edge (30491 eV) XANES spectra are characterised by absorption edge positions separated by only a few eV due to the core-hole lifetime broadening at this edge. While the first derivative of the normalised energy spectra has been shown to reliably discriminate $\mathrm{Sb}(\mathrm{III})$ and $\mathrm{Sb}(\mathrm{V})$ coordinated to oxygen, ${ }^{82}$ differentiating Sb(III) coordinated to oxygen and sulphur, for example, requires the use of extended X-ray absorption fine structure spectroscopy (EXAFS), which has poorer detection limits and much longer analysis times than XANES. ${ }^{83}$ These methods are also unsuitable for measuring methylated Sb species due to their presence at very low concentrations (<5\%). Overall, we recommend that care be taken when using Sb K-edge XAS for environmental samples due to the risk for erroneous interpretation of spectra that only exhibit subtle changes between oxidation states and local coordination environments. Robust statistical assessment of linear combination fit quality (e.g. combinatorial fitting with Hamilton testing, or principal component analysis with target transformation) is critical for ensuring accurate determination of Sb speciation. ${ }^{83,84}$ Ultimately, we expect that the routine application of high energy resolution fluorescence detected XANES (HERFD-XANES) in the near future will overcome the limitations of conventional Sb XANES by providing far lower detection limits and superior spectral resolution. ${ }^{85,86}$ 
Total Sb concentration measurements in plants, animal tissues and sediment require digestion procedures incorporating $\mathrm{HBF}_{4}$, $\mathrm{HF}$ or $\mathrm{HCl}$ to prevent $\mathrm{Sb}$ adsorption to silicates. Methods for Sb speciation should be fit for purpose and appropriate methods are available for volatile $\mathrm{Sb}$ species (SPME-GCMS), waters (hydride generation-trapping ICPMS) and some sediment extracts (HPLC-ICPMS). Measurement of Sb species in other sediments, soils and plants is a challenge due to low extraction efficiencies, Sb oxidation and formation of chromatographic artefacts. Antimony species can be extracted from sediments with citrate when Sb is associated with Fe-Mn oxohydroxide phases. In our view, it is not possible to measure inorganic Sb species in plants and most sediments and soils by HPLC-ICPMS and solid sample measurement techniques such as X-ray absorption spectroscopy should be considered. These techniques, however, will not be able to quantify methylated Sb species at the low concentrations reported in plants and sediments.

Note: Papers cited not freely available can be obtained on request from authors

\section{Acknowledgements}

WWB was funded by the Australian Research Council (DE140100056). Part of this research was undertaken on the X-ray absorption spectroscopy beamline at the Australian Synchrotron, Victoria, Australia.

\section{References}

1. V. Ettler, V. Tejnecký, M. Mihaljevič, O. Šebek, M. Zuna and A. Vaněk, Geoderma, 2010, 155, 409-418.

2. M. Tighe and P. Lockwood, Communications in soil science and plant analysis, 2007, 38, 1487-1501.

3. I. Koch, L. Wang, J. Feldmann, P. Andrewes, K. J. Reimer and W. R. Cullen, International Journal of Environmental Analytical Chemistry, 2000, 77, 111-131.

4. B. Fowler and P. Goering, Metals and their Compounds in the Environment, 1991, 743-750.

5. P. Andrewes and W. R. Cullen, Organometallic Compounds in the Environment, 2003, 277303.

6. O. von Uexküll, S. Skerfving, R. Doyle and M. Braungart, Journal of Cleaner Production, 2005, 13, 19-31.

7. W. Shotyk and M. Krachler, Environmental Science \& Technology, 2007, 41, 1560-1563.

8. Y. Takahashi, K. Sakuma, T. Itai, G. Zheng and S. Mitsunobu, Environmental science \& technology, 2008, 42, 9045-9050.

9. S. Ackermann, R. Gieré, M. Newville and J. Majzlan, Science of the Total Environment, 2009, 407, 1669-1682.

10. S. Keresztes, E. Tatár, V. G. Mihucz, I. Virág, C. Majdik and G. Záray, Science of the Total Environment, 2009, 407, 4731-4735.

11. D. Varrica, F. Bardelli, G. Dongarra and E. Tamburo, Atmospheric environment, 2013, 64, 1824.

12. W. Maher, Analytical Letters, 1986, 19, 295-305.

13. S. Foster, W. Maher, F. Krikowa, K. Telford and M. Ellwood, Journal of Environmental Monitoring, 2005, 7, 1214-1219.

14. R. Miravet, E. Bonilla, J. Lopez-Sanchez and R. Rubio, Journal of Environmental Monitoring, 2005, 7, 1207-1213. 
15. L. AlSioufi, A. M. S. de la Campa and D. Sánchez-Rodas, Microchemical Journal, 2016, 124, 256-260.

16. D. Sanchez-Rodas, L. Alsioufi, A. M. S. de la Campa and Y. Gonzalez-Castanedo, Journal of Hazardous Materials, 2017, 324, 213-220.

17. Y. Cai, Y. Mi and H. Zhang, Journal of hazardous materials, 2016, 316, 102-109.

18. J. Li, Q. Wang, R. S. Oremland, T. R. Kulp, C. Rensing and G. Wang, Applied and environmental microbiology, 2016, 82, 5482-5495.

19. M. O. Andreae, J. F. Asmode, P. Foster and L. Van't dack, Analytical chemistry, 1981, 53, 1766-1771.

20. M. J. Ellwood and W. A. Maher, Journal of Analytical Atomic Spectrometry, 2002, 17, 197203.

21. A. V. Hirner, J. Feldmann, E. Krupp, R. Gruemping, R. Goguel and W. R. Cullen, Organic Geochemistry, 1998, 29, 1765-1778.

22. L. Duester, J. P. Vink and A. V. Hirner, Environmental science \& technology, 2008, 42, 58665871.

23. P. Andrewes, W. R. Cullen, J. Feldmann, I. Koch, E. Polishchuk and K. J. Reimer, Applied organometallic chemistry, 1998, 12, 827-842.

24. R. O. Jenkins, P. J. Craig, W. Goessler, D. Miller, N. Ostah and K. J. Irgolic, Environmental science \& technology, 1998, 32, 882-885.

25. J. Feldmann and A. Hirner, International Journal of Environmental Analytical Chemistry, 1995, 60, 339-359.

26. M. Dodd, S. A. Pergantis, W. R. Cullen, H. Li, G. K. Eigendorf and K. J. Reimer, Analyst, 1996, 121, 223-228.

27. P. Craig, S. Forster, D. Miller and R. Jenkins, Analyst, 1999, 124, 1243-1248.

28. C. Yu, Q. Cai, Z.-X. Guo, Z. Yang and S. B. Khoo, Analyst, 2002, 127, 1380-1385.

29. H. R. Hansen and S. A. Pergantis, Journal of Analytical Atomic Spectrometry, 2006, 21, 731733.

30. W. Maher, S. Forster, F. Krikowa, P. Snitch, G. Chapple and P. Craig, Atomic Spectroscopy, 2001, 22, 361-370.

31. M. Krachler, M. Burow and H. Emons, Analyst, 1999, 124, 777-782.

32. M. Krachler and H. Emons, Fresenius' journal of analytical chemistry, 2000, 368, 702-707.

33. X. Feng, S. Wu, A. Wharmby and A. Wittmeier, Journal of analytical atomic spectrometry, $1999,14,939-946$.

34. J. Warnken, R. Ohlsson, D. T. Welsh, P. R. Teasdale, A. Chelsky and W. W. Bennett, Chemosphere, 2017, 180, 388-395.

35. F. Berry and M. Brett, Journal of Catalysis, 1984, 88, 232-236.

36. A. D. Hewitt and J. H. Cragin, Environmental Science \& Technology, 1991, 25, 985-986.

37. B. Pahlavanpour, M. Thompson and L. Thorne, Analyst, 1980, 105, 756-761.

38. K. Telford, W. Maher, F. Krikowa and S. Foster, Journal of Environmental Monitoring, 2008, 10, 136-140.

39. M. Tighe, P. Ashley, P. Lockwood and S. Wilson, Science of the Total Environment, 2005, 347, 175-186.

40. M. Tighe, P. Lockwood and S. Wilson, Journal of Environmental Monitoring, 2005, 7, $1177-$ 1185.

41. M. Filella and P. M. May, Geochimica et Cosmochimica Acta, 2003, 67, 4013-4031.

42. S. Mitsunobu, T. Harada, K. Hoshino and Y. Takahashi, Chemistry Letters, 2005, 34, 16561657.

43. R. Boyle and I. Jonasson, Journal of Geochemical Exploration, 1984, 20, 223-302.

44. A. Anderson, S. Sharma, S. Wang and Z. Wang, Journal of Raman spectroscopy, 1998, 29, 251-255. 
45. A. Robbat jr and R. L. Simpson lii, Fresenius' journal of analytical chemistry, 1999, 364, 305312.

46. M. J. Nash, J. E. Maskall and S. J. Hill, Journal of Environmental Monitoring, 2000, 2, 97-109.

47. M. Tighe, P. Lockwood, S. Wilson and L. Lisle, Communications in soil science and plant analysis, 2004, 35, 1369-1385.

48. W. Quiroz, F. Astudillo, M. Bravo, F. Cereceda-Balic, V. Vidal, M. R. Palomo-Marín, F. RuedaHolgado and E. Pinilla-Gil, Microchemical Journal, 2016, 129, 111-116.

49. L. Smith, W. Maher, P. Craig and R. Jenkins, Applied organometallic chemistry, 2002, 16, $287-$ 293.

50. I. Koch, J. Feldmann, J. Lintschinger, S. Serves, W. Cullen and K. Reimer, Applied organometallic chemistry, 1998, 12, 129-136.

51. L. Duester, R. A. Diaz-Bone, J. Kösters and A. V. Hirner, Journal of Environmental Monitoring, 2005, 7, 1186-1193.

52. R. A. Diaz-Bone and M. Hitzke, Journal of Analytical Atomic Spectrometry, 2008, 23, 861-870.

53. M. Dodd, S. L. Grundy, K. J. Reimer and W. R. Cullen, Applied organometallic chemistry, 1992, 6, 207-211.

54. I. De Gregori, W. Quiroz, H. Pinochet, F. Pannier and M. Potin-Gautier, Talanta, 2007, 73, 458-465.

55. Y. Morita, T. Kobayashi, T. Kuroiwa and T. Narukawa, Talanta, 2007, 73, 81-86.

56. A. Mestrot, Y. Ji, S. Tandy and W. Wilcke, Environmental Chemistry, 2016, 13, 919-926.

57. J. Lintschinger, I. Koch, S. Serves, J. Feldmann and W. Cullen, Fresenius' journal of analytical chemistry, 1997, 359, 484-491.

58. Z. Fu, G. Zhang, H. Li, J. Chen, F. Liu and Q. Wu, Journal of soils and sediments, 2016, 16, 2471-2481.

59. I. Herath, M. Vithanage and J. Bundschuh, Environmental Pollution, 2017.

60. V. Ettler, M. Mihaljevič, O. Šebek and Z. Nechutný, Chemosphere, 2007, 68, 455-463.

61. Y.-A. Lin, S.-J. Jiang and A. Sahayam, Food Chemistry, 2017, 230, 76-81.

62. M. Filella and P. A. Williams, Environmental toxicology, 2010, 25, 431-439.

63. J. Zheng, A. lijima and N. Furuta, Journal of Analytical Atomic Spectrometry, 2001, 16, 812818.

64. G. E. Parris and F. Brinckman, Environmental science \& technology, 1976, 10, 1128-1134.

65. C. Wei, Z. Ge, W. Chu and R. Feng, Environmental and experimental botany, 2015, 109, $31-$ 39.

66. Y. Wang, L. Chai, Z. Yang, H. Mubarak, R. Xiao and C. Tang, International journal of phytoremediation, 2017, 19, 97-103.

67. R. Feng, C. Wei, S. Tu, S. Tang and F. Wu, Microchemical Journal, 2011, 97, 38-43.

68. G. Scarano and E. Morelli, Plant Science, 2003, 165, 803-810.

69. J. S. Weis and P. Weis, Environment international, 2004, 30, 685-700.

70. R. Haverkamp and A. Marshall, Journal of Nanoparticle Research, 2009, 11, 1453-1463.

71. M. Filella and P. M. May, Journal of Environmental Monitoring, 2005, 7, 1226-1237.

72. S. Amereih, T. Meisel, E. Kahr and W. Wegscheider, Analytical and bioanalytical chemistry, 2005, 383, 1052-1059.

73. C. Hansen, B. Schmidt, E. H. Larsen, B. Gammelgaard, S. Stürup and H. R. Hansen, Analyst, 2011, 136, 996-1002.

74. T. Sh, C.-Q. Liu and L. Wang, Microchemical Journal, 2012, 103, 68-73.

75. H. R. Hansen and S. A. Pergantis, Journal of Analytical Atomic Spectrometry, 2006, 21, 12401248.

76. A. Guy, P. Jones and S. J. Hill, Analyst, 1998, 123, 1513-1518.

77. A. B. Guy, 1999.

78. T. Lindemann, A. Prange, W. Dannecker and B. Neidhart, Fresenius' journal of analytical chemistry, 2000, 368, 214-220. 
79. A. C. Scheinost, A. Rossberg, D. Vantelon, I. Xifra, R. Kretzschmar, A.-K. Leuz, H. Funke and C. A. Johnson, Geochimica et Cosmochimica Acta, 2006, 70, 3299-3312.

80. X. Wan, M. Lei and T. Chen, Environmental Science and Pollution Research, 2016, 23, 1917319181.

448 81. M. Gräfe, E. Donner, R. N. Collins and E. Lombi, Analytica chimica acta, 2014, 822, 1-22.

449 82. S. E. Fawcett, R. A. Gordon and H. E. Jamieson, American Mineralogist, 2009, 94, 1377-1387. 2017, 14, 345-349.

84. S. Calvin, XAFS for Everyone, CRC press, 2013.

85. K. Hämäläinen, D. Siddons, J. Hastings and L. Berman, Physical review letters, 1991, 67, 2850.

86. M. Bauer, Physical Chemistry Chemical Physics, 2014, 16, 13827-13837. 
Water

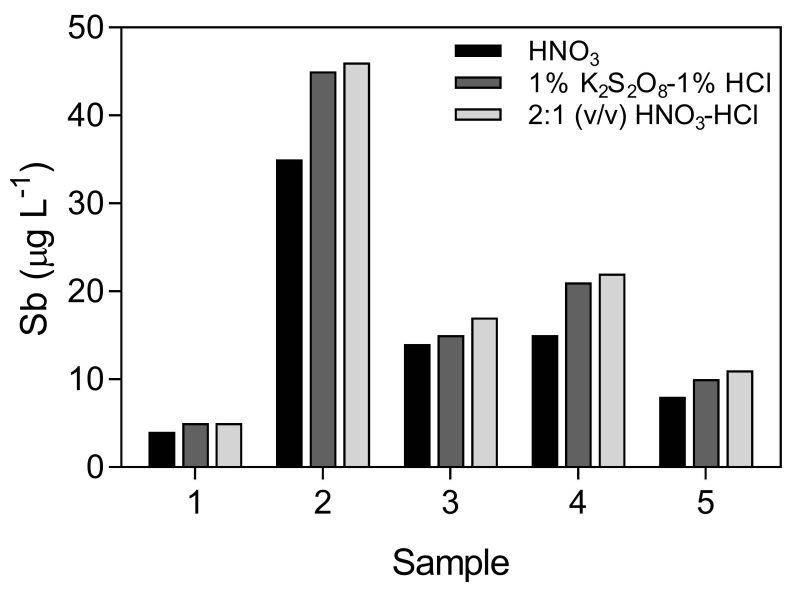

Plants

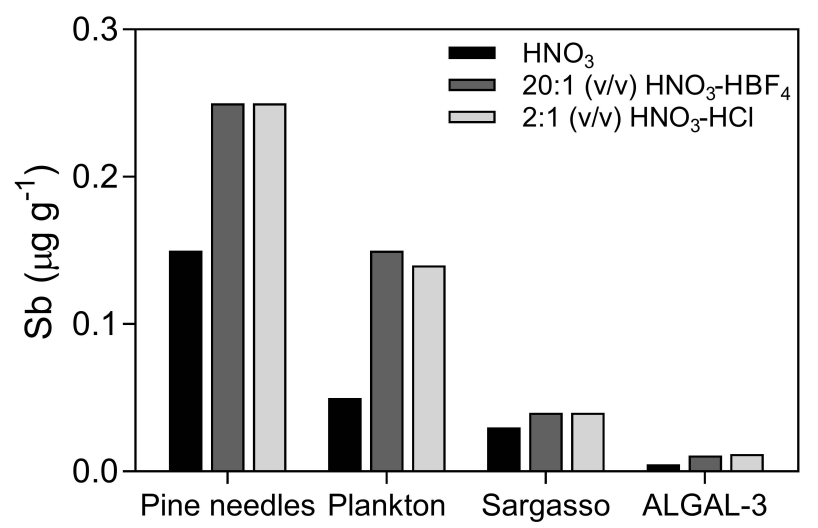

Sediments

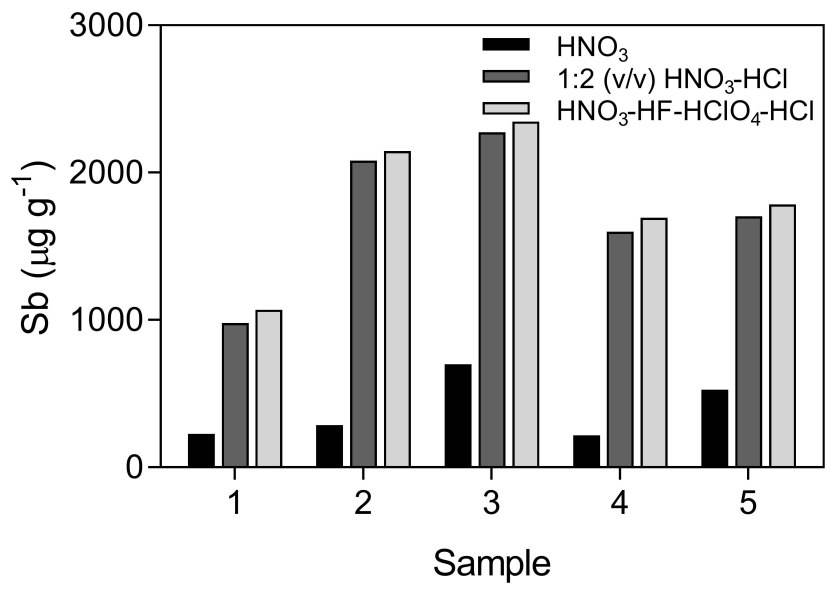

Air Particulates

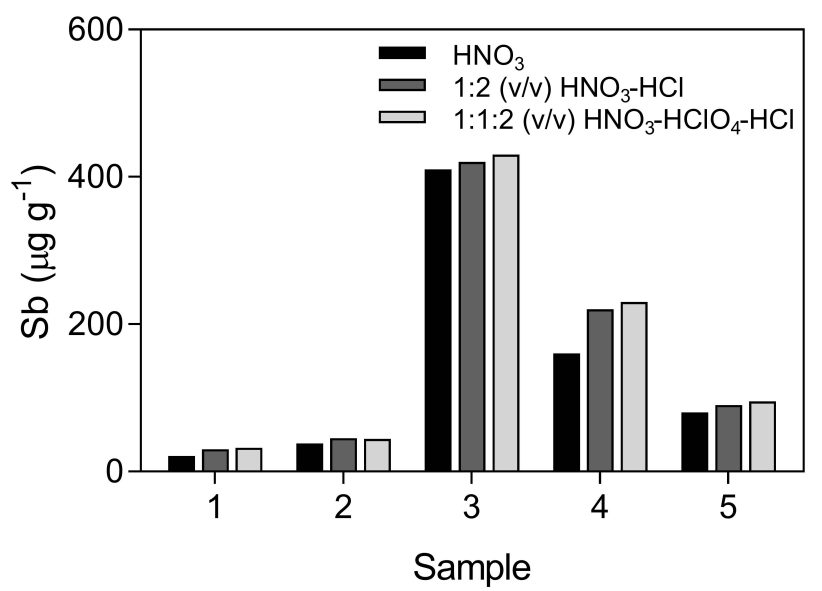




\section{SPME-GC-MS}

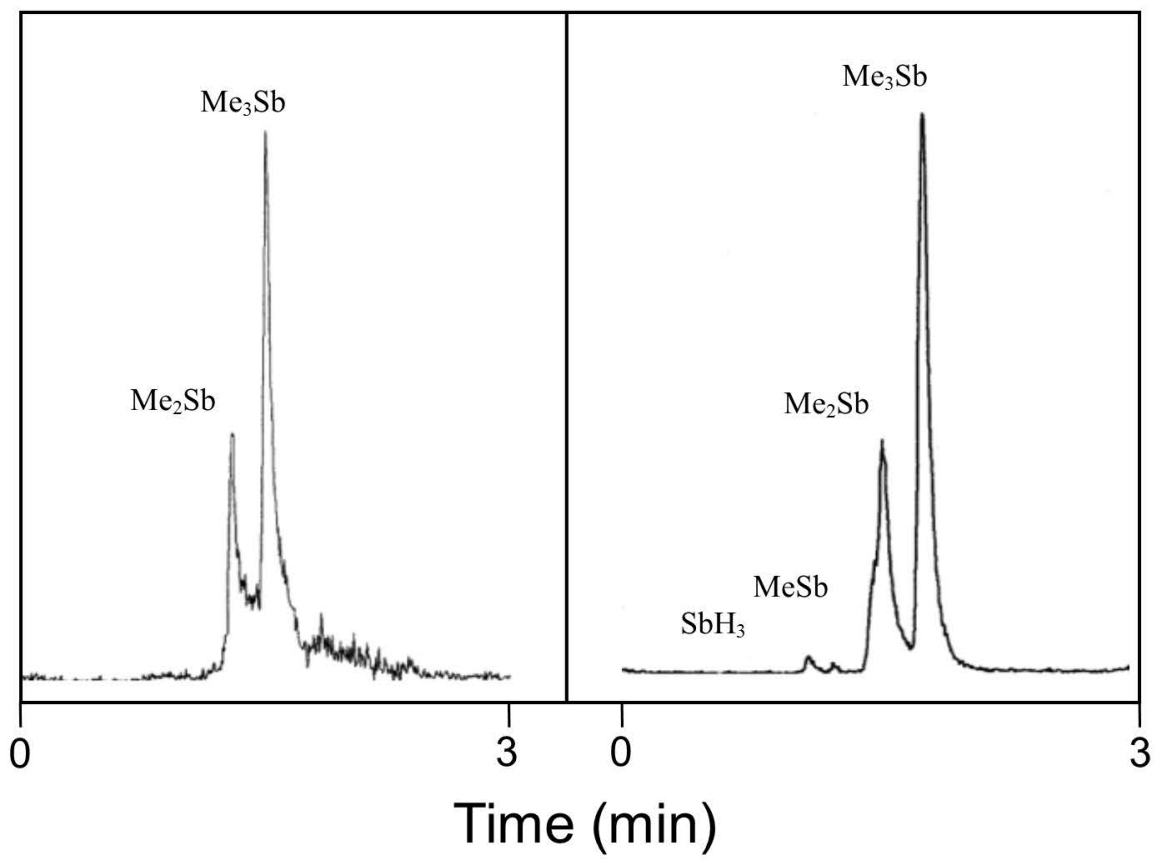

HG-CT-ICPMS

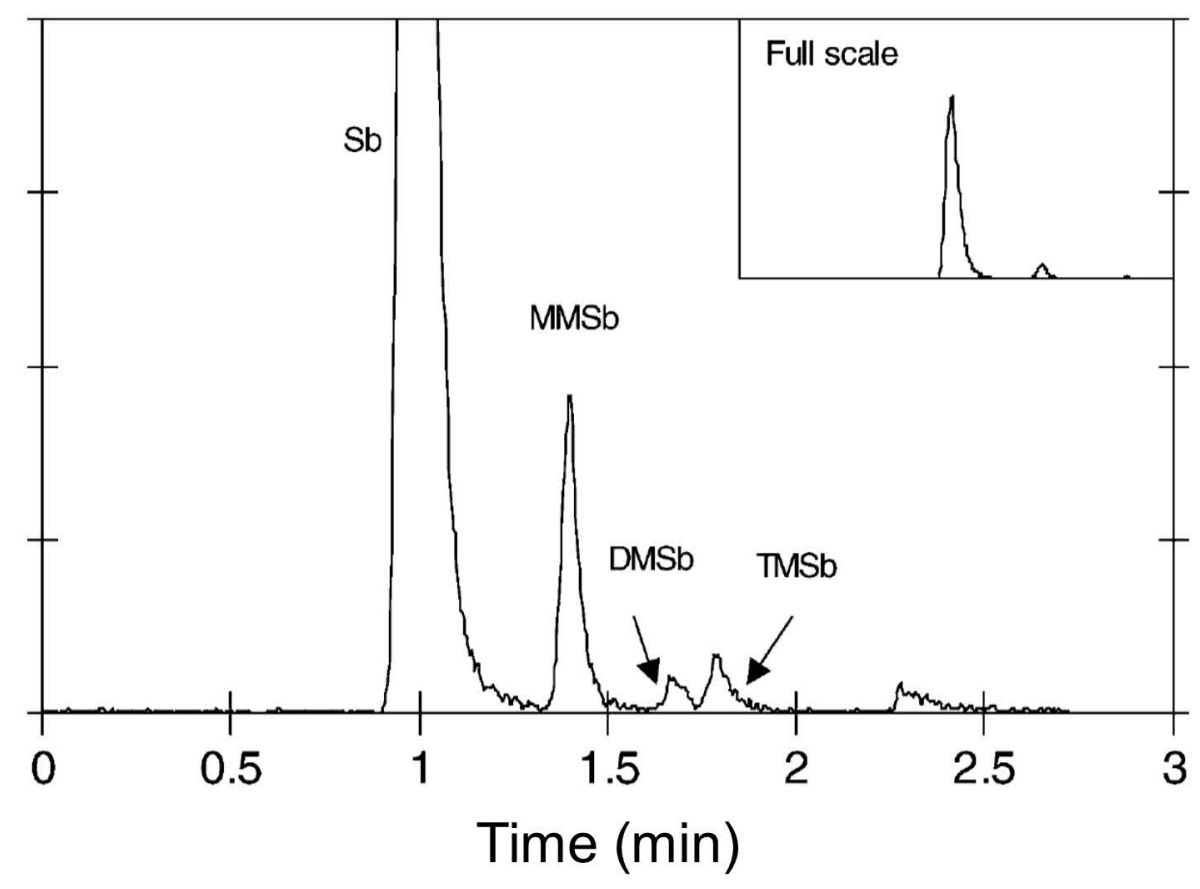

HPLC-ICPMS

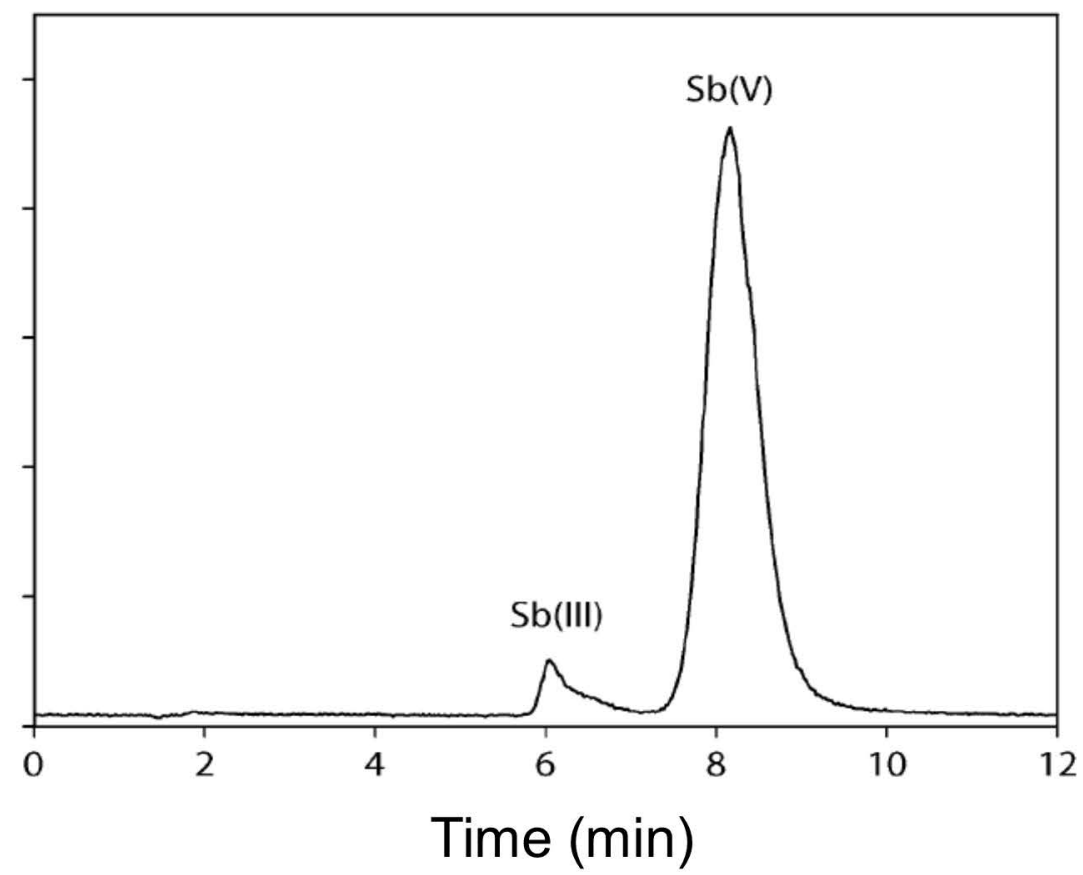

XAS

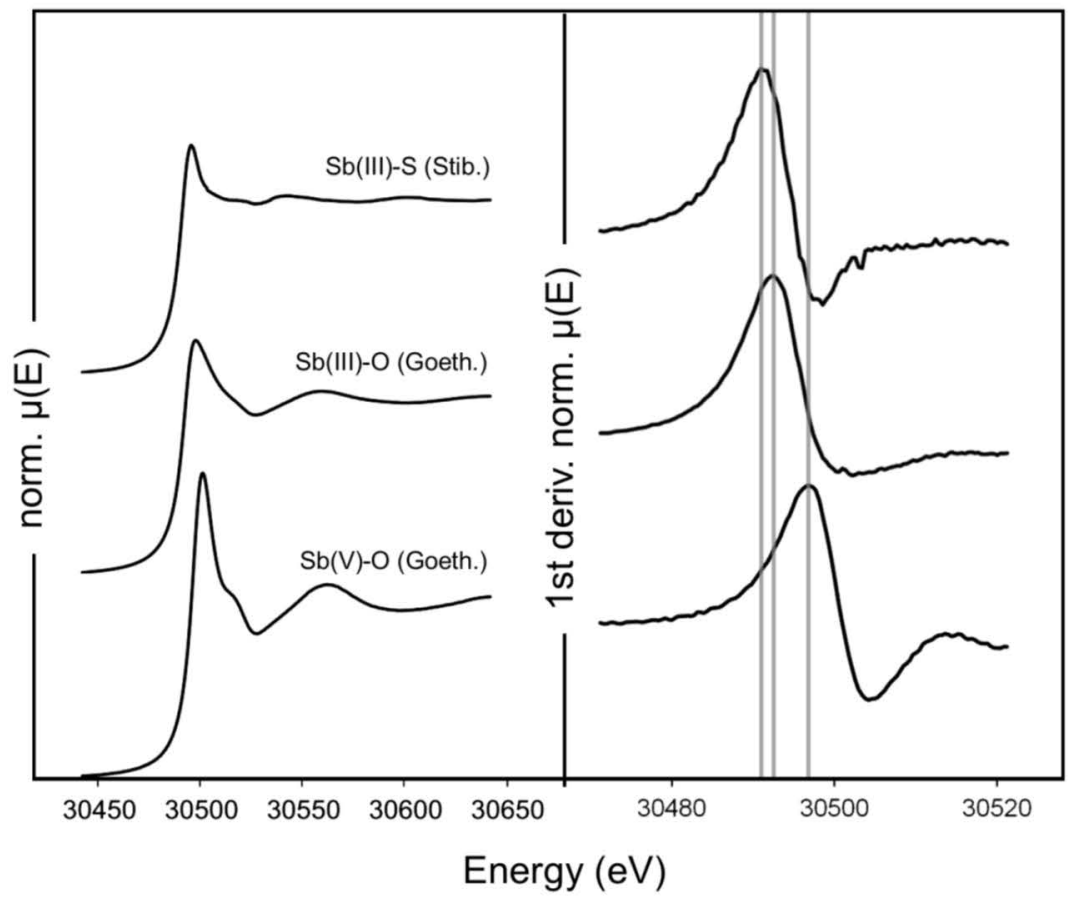

